\title{
Threat Type, Personality \& Policy Preferences
}

\author{
Elizabeth R. Nugent"
}

December I4, 2020

\begin{abstract}
A robust literature in political psychology finds that exposure to threat increases support for illiberal policies through the activation of authoritarian and system-justifying personality traits. However, these studies tend to analyze different threats in isolation or utilize bundled real-world threats in ways that complicate scholars' ability to compare the size of effects across different types or to make causal claims. This paper presents the design and results of a survey experiment designed to isolate specific kinds of threat through four treatment groups priming economic, physical, infrastructure, and identity threats (with a pure control group). The experiment was embedded in a survey of a nationally representative sample of Egyptian adults in December 20I8. Results demonstrate that different kinds of threats have different effects on policy preferences. Respondents assigned to the economic treatment were significantly more supportive of illiberal policies, while those in the security treatment were not, and those in infrastructure and identity treatments showed mixed results. In addition, the results show that different threats interact differently with underlying personality traits. In sum, my findings strongly suggest that all threats do not exert the same influence over policy preferences, and that researchers must disaggregate threat into specific components to fully understand its relationship with policy preferences.
\end{abstract}

\footnotetext{
"Assistant Professor, Department of Political Science, Yale University. Contact: elizabeth.nugent@yale.edu The author acknowledges the Whitney and Betty MacMillan Center for International and Area Studies at Yale University for generously funding this project. Thanks to Nicholas Lotito, Anne Meng, Bruce Rutherford, and audiences at the untenured faculty workshop in Yale's department of political science, the 2019 annual meeting of the Middle East Studies Association, and the Politics of Authoritarian Regimes mini-conference at the 2020 annual meeting of the Southern Political Science Association.
} 


\section{Introduction}

A robust literature in political psychology finds that threat exposure affects policy preferences. When exposed to economic, physical, structural, or moral threats, those who perceive an individual (rather than a sociotropic) threat articulate higher support than the unexposed for illiberal policies, including the use of force, infringement on civil liberties, and autocratic governance 1 Exposure to threat is also correlated with higher support for politicians who advocate illiberal policies. ${ }^{2}$ However, the relationship between threat and policy preferences is not deterministic. Instead, threat activates underlying personality traits - immutable core attributes, stable and consistent within an individual over the course of the life-cycle $\oint^{3}-$ which then alters policy preferences. Threat increases support for illiberal policies when it activates authoritarian and system-justifying personality traits. 4 Authoritarian personality is characterized by a high willingness to obey authority, a high obedience to conventional in-group norms, and aggressive behavior towards outgroups.5 Those who rank higher on authoritarianism tend to hold more illiberal, more hawkish, and more conservative (as commonly understood on the left-right scale)

पDarren W. Davis and Brian D. Silver, "Civil Liberties vs. Security: Public Opinion in the Context of the Terrorist Attacks on America," American Journal of Political Science 48, no. I (2004): 28-46; Leonie Huddy et al., "Threat, Anxiety, and Support of Antiterrorism Policies," American Journal of Political Science 49, no. 3 (2005): 593-608; Karen Stenner, The Authoritarian Dynamic (Cambridge University Press, 2005); Jennifer L. Merolla and Elizabeth J. Zechmeister, Democracy at Risk: How Terrorist Threats Affect the Public (University of Chicago Press, 2009); Bethany Albertson and Shana Kushner Gadarian, Anxious Politics: Democratic Citizenship in a Threatening World (Cambridge University Press, 2015).

2Thomas Pepinsky, “Southeast Asia: Voting Against Disorder," Journal of Democracy 28, no. 2 (2017): 120-I31; Caroline Abadeer et al., "Did Egypt's Post-Uprising Crime Wave Increase Support for Authoritarian Rule?” (Working paper, 2019).

B Avshalom Caspi, Brent W. Roberts, and Rebecca L. Shiner, "Personality Development: Stability and Change," Annual Review of Psychology 56 (2005): 453-484; Alan S. Gerber et al., "The Big Five Personality Traits in the Political Arena," Annual Review of Political Science I4 (2011): $265-287$.

4 Stanley Feldman and Karen Stenner, "Perceived Threat and Authoritarianism," Political Psychology I8, no. 4 (1997): 74I770; Edward J. Rickert, "Authoritarianism and Economic Threat: Implications for Political Behavior," Political Psychology 19, no. 4 (1998): 707-720; Davis and Silver, "Civil Liberties vs. Security: Public Opinion in the Context of the Terrorist Attacks on America|; Huddy et al., “Threat, Anxiety, and Support of Antiterrorism Policies"; John T. Jost and Orsolya Hunyady, "Antecedents and Consequences of System-Justifying Ideologies," Current Directions in Psychological Science I4, no. 5 (2005): 260-265; Howard Lavine, Milton Lodge, and Kate Freitas, "Threat, Authoritarianism, and Selective Exposure to Information," Political Psychology 26, no. 2 (2005): 219-244; Stenner, The Authoritarian Dynamic Merolla and Zechmeister, Democracy at Risk: How Terrorist Threats Affect the Public, Albertson and Gadarian, Anxious Politics: Democratic Citizenship in a Threatening World Samuel Greene and Graeme Robertson, "Agreeable Authoritarians: Personality and Politics in Contemporary Russia," Comparative Political Studies 50, no. 13 (2017): 1802-1834.

5Theodor Adorno et al., The Authoritarian Personality (Verso Books, 2019[1950]); Robert A. Altemeyer, Right-Wing Authoritarianism (University of Manitoba Press, 1981); Robert A. Altemeyer, The Authoritarian Specter (Harvard University Press, 1996). 
policy preferences.$^{6}$ Threat has been found to most affect the least authoritarian in a population, rendering those individuals similar to the strongest authoritarians in a kind of bump-up effect. Similarly, system justification is a personality type characterized by a tendency to bolster, justify, and defend the status quo, with a particular commitment to the societal status quo. Group members passively reflect stable and legitimate status systems, which are deeply ingrained in their psyche. With regards to political preferences, those who rank higher on system justification scales tend to be more politically conservative (again, as commonly understood on the left-right scale).7]

While the strengths of this literature are many, I highlight a central limitation. Studies on threat and support for illiberal policies tend to analyze different threats in isolation, singling out one type of threat to study its effect in a certain time and place, or utilize real-world threats that may serve as a bundled treatment. This challenges our collective ability to compare the effects of different kinds of threats and how they activate personality traits relative to other threats. In this paper, I present the design and results of a survey experiment that builds on existing studies on threat, personality, and policy preferences. I designed the experiment to isolate specific kinds of threat through four treatment groups priming economic, physical, infrastructure, and identity threats (with a pure control group). This design choices allows me to test the relative strength of each kind of threat on support for illiberal policies and its interaction with personality traits within the same population at the same time. In line with existing studies, the survey included measurements of threat perception at the national- and individual-level. I also included established batteries measuring authoritarian personality and for system justification to test whether personality traits condition the relationship between threat perception and support for illiberal policies.

The experiment was embedded in a survey of a nationally representative sample of Egyptian adults in December 2018 (case selection is discussed in more detail in the following section). Results demonstrate that different kinds of threats have different effects on policy preferences. Respondents in

${ }_{6}^{6}$ Stenner, The Authoritarian Dynamic, Marc J. Hetherington and Jonathan D. Weiler, Authoritarianism and Polarization in American Politics (Cambridge University Press, 2009).

ZJohn T Jost, Aaron C Kay, and Hulda Thorisdottir, Social and Psychological Bases of Ideology and System Justification (Oxford University Press, 2009). 
the economic, infrastructure, and identity treatments were significantly more likely to report that the threat would affect them, while those in the security treatment were not. Similarly, respondents assigned to the economic treatment were significantly more supportive of illiberal policies, while those in the security treatment were not (the infrastructure and identity treatments showed mixed results). Finally, the experimental results provide some evidence that underlying personality traits interact differently with different kinds of threat, affecting those who score low on authoritarian personality and system justification differently than those with higher scores (though not always at the level of statistical significance).

\section{Experimental Design}

The experiment analyzed in this paper was embedded in a nationally representative survey of 2,000 Egyptian adult citizens conducted in December 2018.8 The instrument included questions capturing respondents' political behavior, policy preferences, emotions, personality and demographic information. While a survey experiment does not allow me to test how long the effects might endure, the combination of a nationally representative sample and an experimental manipulation provides a reliable test of causal propositions about the way in which exposure to different kinds of threat relate to the expression of particular attitudes. 9

Egypt is an ideal if hard case in which to test questions surrounding the relationship between threat, personality, and policy preferences. The country has been an authoritarian regime since its independence in 1952. Following the 20II 'Arab Spring' uprisings, Egypt witnessed a brief democratic opening. However, since coming to power in a 2013 coup, military president Abdel Fattah al-Sisi has overseen authoritarian retrenchment on a scale that dwarfs the policies of his predecessors. Economically, Egyptians' living conditions are rapidly deteriorating due to chronic mismanagement of public finance. Nearly $58 \%$ of public resources goes towards debt and loan repayment, resulting in meager spending on health, education, and other basic social services for the country's Ioo million citizens. The World Bank reports

QDiana C Mutz, Population-Based Survey Experiments (Princeton University Press, 20II). 
that at present 6o\% of Egypt's population is either poor or vulnerable. Relatedly, Egypt's rapidly aging infrastructure increasingly puts Egyptians at high risk due to food insecurity, pollution, and poorly maintained roads and public transport systems. ${ }^{\mathrm{IO}}$ The current regime came to power by ousting democratically elected president Mohamed Morsi of the Muslim Brotherhood. Since 2013, the regime has paired mass arrests of tens of thousands of accused supporters with a smear campaign against the Brotherhood painting the organization as an existential threat to the country. ${ }^{m}$ Egypt regularly witnesses terrorist attacks and large swathes of territory remain beyond government control. For the past five years, the Egyptian military has conducted persistent counter-terrorism operations in Sinai against an Islamic State affiliate with the help of billions of dollars in American aid, many of which are broadcast on national television. The regime intentionally blur the lines between moderate Islamist organizations and violent militant ones, and often conflates the security and identity threats they pose.

Despite these significant issues, Sisi remains quite popular, and much of this support appears to be genuine $\mathrm{I}^{12}$ The question that inspired this paper and experiment was what might explain Sisi's seemingly legitimate popularity while Egypt faces so many significant economic, security, and political crises. Previous research has established that citizen support, both in aligned policy preferences and in compliant behavior, is critical to the stability and survival of autocratic regimes ${ }^{13}$ If perceived by individuals as threats, these crises of governance may actually be driving support for Sisi rather than undermining it. Egypt is thus a "most likely" case for observing the effects of threat on support for illiberal policies, but may also be a difficult case in which to manipulate threat perception given the saturation of threats in the current national moment.

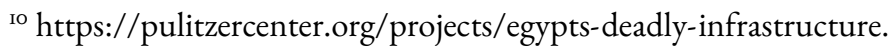

四 As detailed by independent statistical database Wiki Thawra in a report titled "Report on the Detained and Prosecuted during the Sisi/Adly Mansour Period.” Available in Arabic at https://wikithawra.wordpress.com/20I4/or/og/ sisi-mansour-detainees/.

12 Rory Truex and Daniel L. Tavana, "Implicit Attitudes toward an Authoritarian Regime," The Journal of Politics 8I, no. 3 (2019).

13 Ronald Wintrobe, "Some Lessons on the Efficiency of Democracy from a Study of Dictatorship," in The Political Dimension of Economic Growth (Springer, 1998), 20-37; Barbara Geddes, "Why parties and elections in authoritarian regimes?," in annual meeting of the American Political Science Association (2005), 456-471; Beatriz Magaloni, Voting for Autocracy: Hegemonic Party Survival and its Demise in Mexico, vol. 296 (Cambridge University Press, 2006); Steven Levitsky and Lucan A Way, Competitive Authoritarianism: Hybrid Regimes after the Cold War (Cambridge University Press, 20Io).
} 


\section{Experimental Treatment Conditions}

Respondents were randomly assigned to one of five treatment conditions, with each treatment group totaling 400 individuals. The experiment was designed to subtly and ethically prime different kinds of threats among respondents in a conversational but thorough manner. I constructed treatments to be consistent in how they described threat, including quantitative statistics and qualitative descriptions of the specific threat and how people might experience it, and similar in length. The randomization of the treatments succeeded with respect to pre-treatment covariates and observables ${ }^{[4}$ Respondents were read one of the following paragraphs:

\section{Control: No text.}

2. Economic Treatment: As you may know, Egypt has experienced a national economic crisis in recent years. Poverty rates have soared, reaching 6o percent in some governorates, and inflation of the Egyptian pound rose as high as 35 percent in 2017. Unemployment has remained very high at above Io percent. In addition, prices for basic commodities such as bread, oil, public transportation, and electricity have nearly doubled. This economic crisis threatens the country.

3. Terrorism Treatment: As you may know, Egypt has experienced a national security crisis in recent years. Terrorism rates have soared, reaching 1700 attacks in the Sinai, and 225 attacks and 877 civilian fatalities at the national level in 2017. Almost Iooo police officers and soldiers have been killed while fighting extremists and insurgents. In addition, the number of attacks in urban centers has increased dramatically. This security crisis threatens the country.

4. Infrastructure Treatment: As you may know, Egypt has experienced a national infrastructure crisis in recent years. Infrastructure accidents have soared, reaching II,098 incidents and 3,747 fatalities related to poor road conditions at the national level in 20I7. The number of collapsed buildings due to poor maintenance exceeded one per week. In addition, the number of accidents involving the Egyptian National Railways increased by nearly a third. This infrastructure crisis threatens the country.

5. Identity Treatment: As you may know, Egypt has experienced a national identity crisis in recent years. Violent sectarian incidents have soared, reaching 77 major attacks in 2017. While recent public opinion data suggests that the majority of the country acknowledges Egypt as a civil-secular state that respects Islamic tenets, as many as one fifth of Egyptians want the government to adopt more strict and literal interpretations of Islam. In addition, the number of Egyptian citizens who use an adjective in their self-description, such as Muslim or Christian Egyptian, has grown in recent years. This identity crisis threatens the country.

${ }^{14}$ See table I in the paper's appendix. 


\section{Outcome Variables}

The main post-treatment questions of interest capture policy preferences. Responses were coded as I for choosing the more illiberal option (option a for both questions) and o for choosing the more liberal option (option b in both questions). Answer order was randomized across respondents.

I. Which of the following two options is closer to your opinion?

a. "A non-democratic government can be preferable under some circumstances."

b. "A non-democratic government is never preferable under any circumstances."

2. Which of the following two options is closer to your opinion?

a. "During times of crisis, it is important to have a strong leader decide the best policies."

b. "During times of crisis, it is important to have the people vote to decide the best policies."

Two additional post-treatment questions measured respondents' perceptions of threats at the national- and individual-level. All respondents in all treatment groups were asked the first question in its entirety, with the order of the answer options randomized. For the second question, respondents assigned to an active treatment condition were only asked about the national crisis mentioned in the treatment text (economic, security, infrastructure, or identity). In the control group, respondents were asked about all four types of crises, with the question order randomized, so that the effect of each treatment could be compared with a baseline level.

I. In your opinion, which of the following is the most important challenge facing Egypt today?

- Achieving economic stability

- Maintaining national security

- Improving infrastructure

- Solving identity issues

2. To what extent do you worry that a national [...] crisis will negatively affect you, your family, and people like you?
a. Economic
b. Security/terrorism
c. Infrastructure 


\section{d. Identity}

Answer choices: To a great extent, to a medium extent, to a small extent, not at all, don't know (do not read), refuse (do not read)

\section{Main Results: Threat Type and Support for Illiberal Policies}

First, are individuals threatened to the same extent by different kinds of threat? The results, presented visually in figure I $_{\text {s }}$ suggest that they are, and different kinds of threats have larger effects than others. Recall that two post-treatment questions asked about perceptions of national- and individuallevel threat. For the first question, respondents were asked about the most important challenge facing Egypt today, and were able to choose one among the economic, security, infrastructure, and identity answer options. There was no significant difference in answers between the control and economic treatment, although this is likely due to ceiling effects; 7I percent of respondents chose the economy as the most important challenge facing Egypt, and it was statistically indistinguishable from the 69 percent who choose the same option in the economic treatment condition. In the security treatment, 27 percent of respondents chose the security response option (verses I8.9 percent in the control), at the expense of economic challenges (which dropped to 63 percent). In the infrastructure treatment condition, I2 percent of respondents chose this option (versus 9 percent in the control), and finally 4 percent of respondents chose an identity threat in the identity treatment condition (versus .os percent in the control). A second post-treatment question asked about perceptions of individual-level threat. Recall that respondents were asked to rank on a categorical scale of I to 4 , where $\mathrm{i}$ indicated "not at all" and 4 indicated "to a great extent," to what extent the primed threat would affect them. In the control group, respondents were asked about all four threats in order to compare with the treatment groups. Figure ?? below demonstrates that all differences were significant at the 95 percent level save the security treatment; the economic treatment averaged 3.78 in comparison with an average of 3.62 in the control, the infrastructure treatment averaged 3.20 in comparison with a 3.02 average in the control; and the identity treatment averaged 2.87 in comparison with a 2.56 average in the control. Taken together, these results suggest that priming a specific threat 
increased its salience in the minds of respondents and rendered them more likely to rank that prime as a major threat to their country. In addition, individuals were significantly more likely to feel that they personally could fall victim to a threat in the economic, infrastructure, and identity treatments.
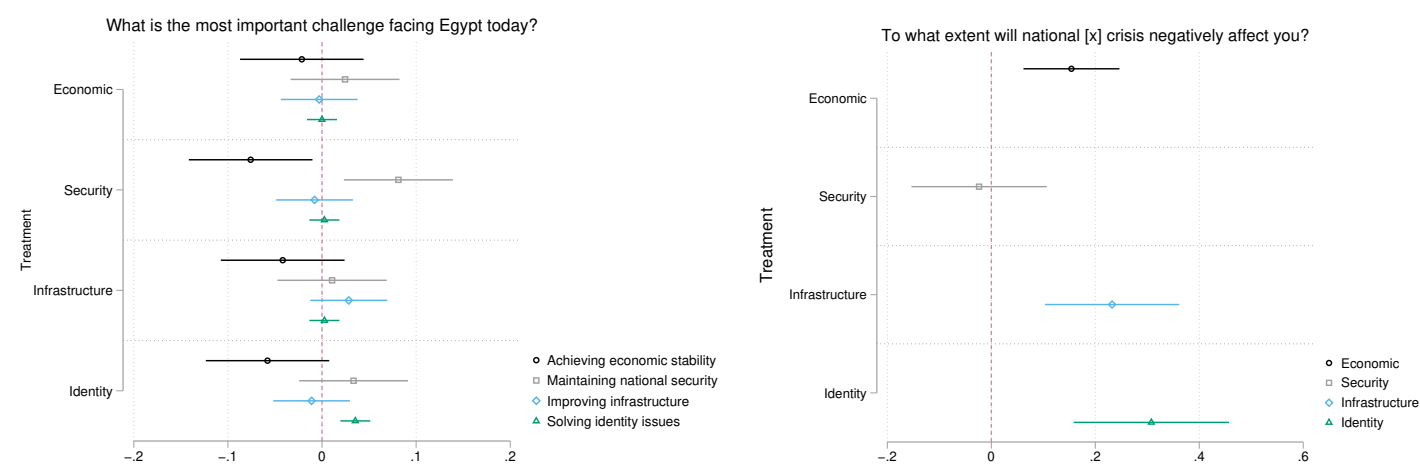

Figure I: Perceptions of Threat by Treatment Assignment

Second, does the type of threat an individual faces matter in whether they become more (less) supportive of illiberal policies? The results suggest that the answer to this question is yes. Figure ?? demonstrates the average treatment effects on the post-treatment questions measuring policy preferences, comparing response rates and the level of statistical significance of the difference with the untreated control. Recall that respondents faced a force-choice answer between one of two statements. In the control group, 46.o percent of respondents expressed support for the statement "a non-democratic government can be preferable under some circumstances." Respondents were significantly more supportive of the statement in the economic and infrastructure treatments - and nearly so in the identity treatment $(\mathrm{p}$ $=0.069$ ). The security treatment did not produce a significant effect. 67.5 percent of respondents in the control group expressed support for the statement, "during times of crisis, it is important to have a strong leader decide the best policies" rather than having people vote to determine the best policies. Respondents' support for the authoritarian policy in the economic, infrastructure, and identity treatments demonstrates a similar pattern to that of the first question, but the effect is only significant for the economic treatment. Similar to the first question about support for authoritarian policies, the security treatment did not produce a significant effect. 


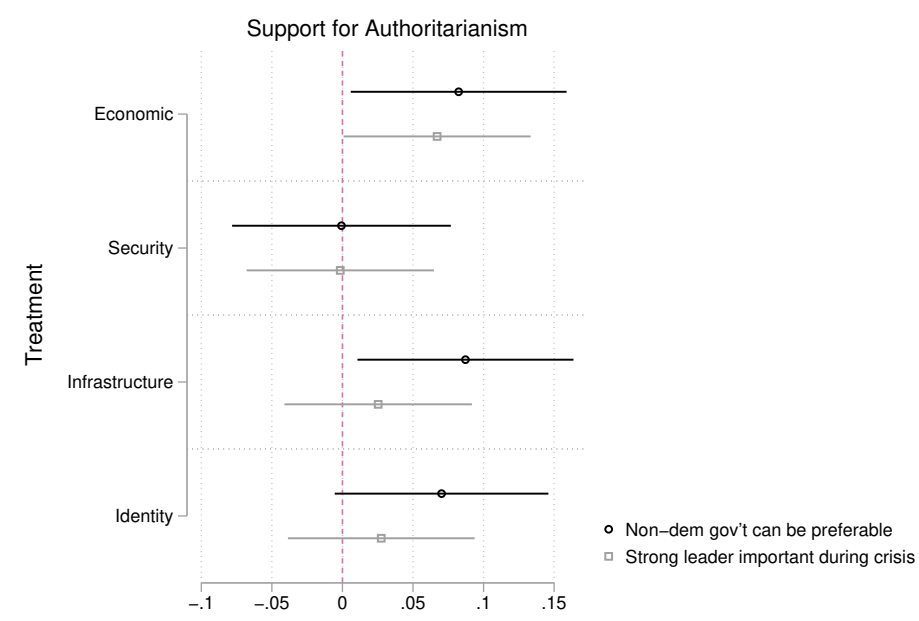

Figure 2: Average Treatment Effects on Support for Illiberal Policies

\section{Mechanism Tests: Threat Type and Personality Activation}

Recall that the survey instrument included batteries capturing two personality types. ${ }^{15}$ First, a pre-treatment battery of questions measured respondents' authoritarian personality by asking established questions about child-rearing used to measure this personality type. Second, a pre-treatment battery measured respondents' level of system justification. To explore whether different kinds of threats differently activated respondents' personality types, I interact the authoritarian personality and system justification indexes with treatment assignment ${ }^{16}$ In figures 3 and 4 , I plot the marginal treatment effect at different levels of the authoritarian personality and system justification indexes to determine whether the significance and direction of the treatments varies by the value of these indexes. The y-axis indicates the direction of the effect: more positive values indicate a stronger positive effect from the treatment at that value of $\mathrm{x}$, while more negative values indicate a stronger negative effect from the treatment at that value of x. Figure 3 demonstrates that there was no significant variation in treatment effect by authoritarian personality, with the exception of the security treatment; respondents who ranked more authoritarian were The appendix contains the full question wording for each.

16 Regression results are presented in table 2 in the paper's appendix. Both batteries are reduced to one question through a mean index. 
most affected by the prime, perhaps in partial explanation of the null average treatment effect defected above. However, for the second question about a strong leader during a crisis, those who ranked less authoritarian were significantly more positively affected by the primes in the economic and infrastructure treatments.
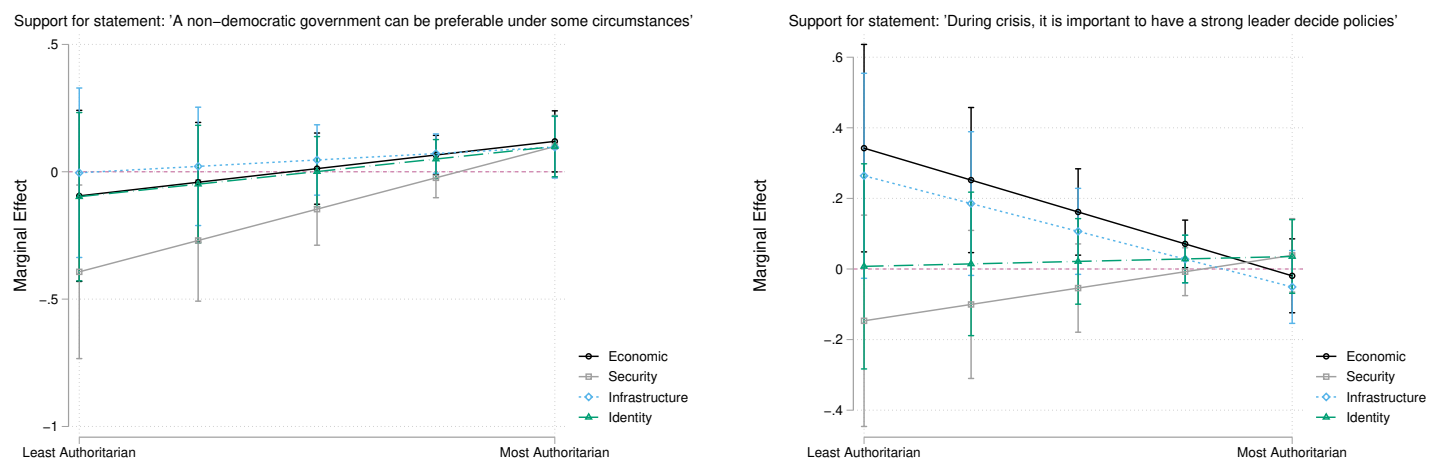

Figure 3: Treatment Effects by Strength of Authoritarian Personality

Figure 4 demonstrates more consistent results for the interaction between treatment and system justification. Respondents who ranked higher on the system justification index were more positively affected by the security, infrastructure, and identity treatments when asked about their support for whether a non-democratic government could sometimes be preferable. Those who ranked higher on system justification were also significantly more supportive of the second statement supporting a strong leader to choose policies during a crisis, though there was not variation in treatment effect.
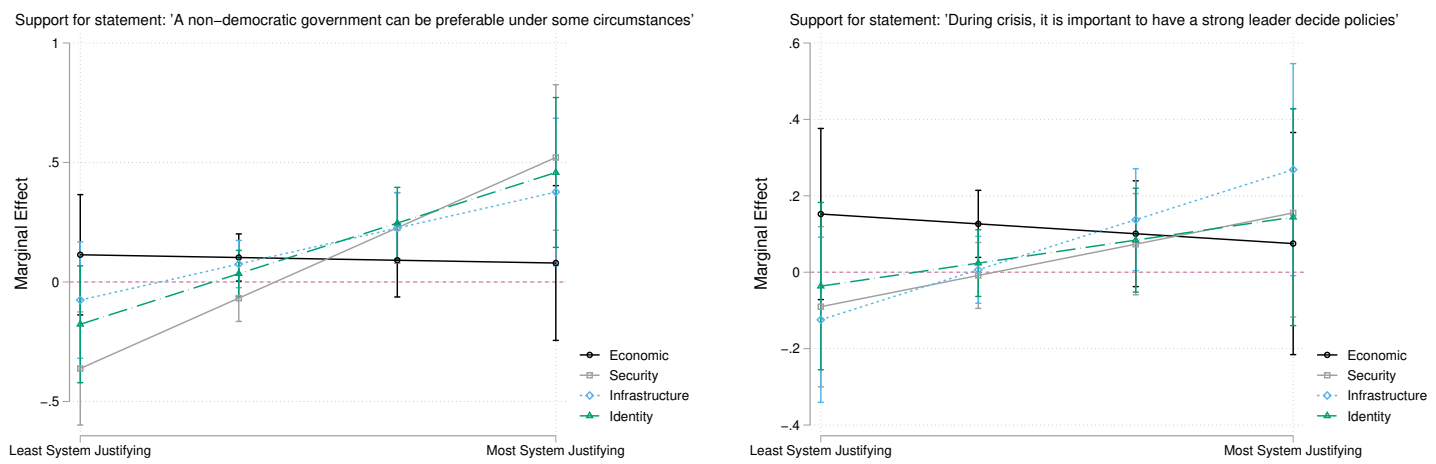

Figure 4: Treatment Effects by Strength of System Justification 


\section{Conclusion}

In this paper, I outlined and analyzed a survey experiment designed to isolate the effect of different kinds of effect on policy preferences. My findings demonstrate that this is a fruitful and necessary approach to understanding threat and preference formation; different kinds of threats exerted different effects on individual threat perception and policy preferences, and interacted differently with underlying personality traits. Among a sample of Egyptian adults, economic threats were particularly effective; those in the economic treatment group were more likely to report that the threat would affect them and more supportive of illiberal policies.

Returning to the puzzle that motivated my inquiry, these results may help to explain Sisi's seemingly sincere popularity despite the variety of crises ongoing and worsening under his rule. If citizens feel these challenges as threats, these crises may actually be reinforcing rather than undermining support for illiberal policies and strongman politics, particularly among those Egyptians who rank low on authoritarian personality and high on system justification. Beyond Egypt, the results might help to explain why authoritarian leaders consistently use propaganda that critics dismiss as fear mongering by outlining the individual-level microfoundations of why it seems to work. ${ }^{17}$ This article demonstrates that personality must be considered in any exploration of why and how individuals support and contribute to the stability of undemocratic regimes.

Future research should continue to test the relationship between threat and illiberal policy preferences in additional national and temporal contexts. In addition, future experimental research on the subject might design an experiment that permits the manipulation of threat perception at the individual level in order to determine how much threat directly affects policy preferences, and how much of its effect is mediated through individual-level threat perception. In doing so, researchers must disaggregate threat into specific components to fully understand its effects on policy preferences. My findings strongly suggest that not all threats are equally important or exert the same influence over policy preferences.

17Haifeng Huang, "Propaganda as Signaling," Comparative Politics 47, no. 4 (2015): 419-444. 


\section{Appendix}

\section{Additional Information on Survey}

The experiment was administered to a nationally-representative sample of 2,ooo Egyptian citizens I8 years and older between November 2I and December 5, 20I8. 30 enumerators employed and trained on the instrument by the Egyptian Research and Training Center (al-Markazal-Misrilil-Bubuth wa al-Tadrib), a survey research firm headquartered in Cairo, Egypt, conducted the face-to-face interviews.

Households were selected from the master sample of households maintained by the Central Agency of Public Mobilization and Statistics (al-Jibaz al-Markazi lil-Ta'bi'a al-Amma waal-Ibsa, or CAPMAS) and drawn from the country's most recent census, conducted in 2017. The sample is drawn from 22 of Egypt's 27 governorates. The excluded five districts (New Valley, North Sinai, Matrouh, Red Sea, and South Sinai) are extremely rural, contain only I.8 percent of the country's population, and its representatives comprised less than 6 percent of the most recently elected representative Egyptian parliament. In addition, the North and South Sinai districts present unique and costly security challenges due to recent turmoil in the area. These give governorates were excluded from the sample due to safety and feasibility concerns, as is standard practice for ERTC and other reputable Egyptian survey firms.

The sampling employed a multi-stage stratified random probability approach so that every member of the 98.2 percentage of the Egyptian population living in the 22 included governorates had an equal chance of being included. The sample was weighted by governorate population (percent of population living within a given governorate per the 2017 census) and stratified by urbanization (45 percent urban and 55 percent rural per the 2017 census). In Egypt's urban governorates, the district is the smallest local governing unit. Within rural governorates, there exist marakez (singular: markaz), which are local governing units over groups of villages, and which are equivalent to districts with the difference in name denoting only its rural characteristic. These governorate sub-units are further divided into PSUs, which each contain $\mathrm{I} 2$ households.

200 PSUs were randomly selected to cover the target sample of 2000 plus twenty percent more in the case of expected respondents who were unavailable or refused to participate. Within each household, the interviewers employed a standard Kish grid method to select individual participants of alternating genders. The final response rate for the survey was 68.26 percent of those approached as a potential respondent. Table I presents the personality and key demographic variables by treatment assignment, demonstrating that randomization largely succeeded and did not impact inferences made from the above analyses. 
Table r: Personality and Demographic Variables by Treatment Assignment

\begin{tabular}{|c|c|c|c|c|c|c|c|c|c|c|}
\hline \multirow[b]{2}{*}{ Variable } & \multicolumn{2}{|c|}{$\begin{array}{c}(\mathrm{I}) \\
\text { Control }\end{array}$} & \multicolumn{2}{|c|}{$\begin{array}{c}(2) \\
\text { Economic }\end{array}$} & \multicolumn{2}{|c|}{$\begin{array}{c}\text { (3) } \\
\text { Security }\end{array}$} & \multicolumn{2}{|c|}{$\begin{array}{c}(4) \\
\text { Infrastructure }\end{array}$} & \multicolumn{2}{|c|}{$\begin{array}{c}(5) \\
\text { Identity }\end{array}$} \\
\hline & $\mathrm{N}$ & Mean/SE & $\mathrm{N}$ & Mean/SE & $\mathrm{N}$ & Mean/SE & $\mathrm{N}$ & Mean/SE & $\mathrm{N}$ & Mean/SE \\
\hline Authoritarian Personality & 399 & $\begin{array}{c}0.795 \\
(0.009)\end{array}$ & 399 & $\begin{array}{c}0.763 \\
(0.009)\end{array}$ & 399 & $\begin{array}{c}0.772 \\
(0.009)\end{array}$ & 397 & $\begin{array}{c}0.767 \\
(0.009)\end{array}$ & 395 & $\begin{array}{c}0.762 \\
(0.009)\end{array}$ \\
\hline System Justification & 308 & $\begin{array}{c}2.304 \\
(0.026) \\
\end{array}$ & 305 & $\begin{array}{c}2.271 \\
(0.025)\end{array}$ & 294 & $\begin{array}{c}2.254 \\
(0.030) \\
\end{array}$ & 301 & $\begin{array}{c}2.279 \\
(0.028) \\
\end{array}$ & 303 & $\begin{array}{c}2.264 \\
(0.027) \\
\end{array}$ \\
\hline Age & 400 & $\begin{array}{l}39.837 \\
(0.678)\end{array}$ & 400 & $\begin{array}{l}38.358 \\
(0.672)\end{array}$ & 400 & $\begin{array}{c}39.502 \\
(0.680)\end{array}$ & 400 & $\begin{array}{l}40.080 \\
(0.673)\end{array}$ & 400 & $\begin{array}{l}38.965 \\
(0.697)\end{array}$ \\
\hline Female & 400 & $\begin{array}{c}0.498 \\
(0.025)\end{array}$ & 400 & $\begin{array}{l}0.490 \\
(0.025)\end{array}$ & 400 & $\begin{array}{l}0.490 \\
(0.025)\end{array}$ & 400 & $\begin{array}{l}0.470 \\
(0.025)\end{array}$ & 400 & $\begin{array}{c}0.498 \\
(0.025)\end{array}$ \\
\hline Education & 400 & $\begin{array}{c}3.773 \\
(0.09 \mathrm{I})\end{array}$ & 400 & $\begin{array}{l}3.777 \\
(0.092)\end{array}$ & 400 & $\begin{array}{l}3.668 \\
(0.095)\end{array}$ & 400 & $\begin{array}{l}3.720 \\
(0.095)\end{array}$ & 400 & $\begin{array}{c}3.630 \\
(0.094)\end{array}$ \\
\hline Employed & 400 & $\begin{array}{l}0.445 \\
(0.025)\end{array}$ & 400 & $\begin{array}{c}0.472 \\
(0.025)\end{array}$ & 400 & $\begin{array}{c}0.458 \\
(0.025)\end{array}$ & 400 & $\begin{array}{l}0.530 \\
(0.025)\end{array}$ & 400 & $\begin{array}{l}0.440 \\
(0.025)\end{array}$ \\
\hline Religiosity & 400 & $\begin{array}{c}2.277 \\
(0.030)\end{array}$ & 400 & $\begin{array}{c}2.328 \\
(0.027)\end{array}$ & 400 & $\begin{array}{c}2.303 \\
(0.029)\end{array}$ & 399 & $\begin{array}{c}2.301 \\
(0.027)\end{array}$ & 399 & $\begin{array}{c}2.288 \\
(0.030)\end{array}$ \\
\hline Economic Stability & 400 & $\begin{array}{c}0.255 \\
(0.022)\end{array}$ & 400 & $\begin{array}{c}0.223 \\
(0.021)\end{array}$ & 400 & $\begin{array}{l}0.240 \\
(0.02 \mathrm{I})\end{array}$ & 400 & $\begin{array}{c}0.215 \\
(0.021)\end{array}$ & 400 & $\begin{array}{c}0.207 \\
(0.020)\end{array}$ \\
\hline
\end{tabular}




\section{Question Wording for Personality Questions}

A. Authoritarian Personality

Now I'd like to ask you a few questions about parenting. There are a number of different values parents can instill in their children. In your opinion, which is the most important in each of the following pairs?

(a) Is it more important for a child to have independence or respect for elders?

(b) Is it more important for a child to obedience or self-reliance?

(c) Is it more important for a child to be considerate or to be well-behaved?

(d) Is it more important for a child to have curiosity or good manners?

B. System Justification

To what extent do you agree with the following statements about your society?

(a) In general, I find society to be fair.

(b) In general, the Egyptian political system operates as it should.

(c) Egyptian society needs to be radically restructured.

(d) Egypt is the best country in the world to live in.

(e) Most policies serve the greater good in Egypt.

(f) Everyone has a fair shot at wealth and happiness in Egypt.

(g) Our society is getting worse every year.

(h) Egyptian society is set up so that people usually get what they deserve.

Answer choices: Strongly Agree, Agree, Disagree, Strongly Disagree, don't know (do not read), refuse (do not read) 
Table 2: Results of Interactions between Personality Types and Treatment Assignment

\begin{tabular}{|c|c|c|}
\hline & $\begin{array}{l}\text { Support for non-dem gov't } \\
\text { as sometimes preferable }\end{array}$ & $\begin{array}{c}\text { Support for strong leader } \\
\text { during crisis }\end{array}$ \\
\hline Authoritarian Personality & $\begin{array}{l}-0.521^{* * *} \\
(0.150)\end{array}$ & $\begin{array}{l}0.048 \\
(0.13 \mathrm{I})\end{array}$ \\
\hline$x$ Economic Treatment & $\begin{array}{c}0.214 \\
(0.214)\end{array}$ & $\begin{array}{l}-0.362^{*} \\
(0.187)\end{array}$ \\
\hline $\mathrm{x}$ Security Treatment & $\begin{array}{l}0.492^{* *} \\
(0.217)\end{array}$ & $\begin{array}{c}0.186 \\
(0.190)\end{array}$ \\
\hline $\mathrm{x}$ Infrastructure Treatment & $\begin{array}{l}0.100 \\
(0.213)\end{array}$ & $\begin{array}{l}-0.315^{*} \\
(0.184)\end{array}$ \\
\hline x Identity Treatment & $\begin{array}{l}0.197 \\
(0.2 \mathrm{II})\end{array}$ & $\begin{array}{l}0.028 \\
(0.185)\end{array}$ \\
\hline System Justification & $\begin{array}{l}-0.019 \\
(0.065)\end{array}$ & $\begin{array}{l}0.135^{* *} \\
(0.057)\end{array}$ \\
\hline $\mathrm{x}$ Economic Treatment & $\begin{array}{l}-0.011 \\
(0.093)\end{array}$ & $\begin{array}{l}-0.026 \\
(0.084)\end{array}$ \\
\hline x Security Treatment & $\begin{array}{l}0.294^{* * *} \\
(0.087)\end{array}$ & $\begin{array}{c}0.082 \\
(0.078)\end{array}$ \\
\hline $\mathrm{x}$ Infrastructure Treatment & $\begin{array}{l}0.150^{*} \\
(0.089)\end{array}$ & $\begin{array}{c}0.13 \mathrm{I} \\
(0.080)\end{array}$ \\
\hline $\mathrm{x}$ Identity Treatment & $\begin{array}{l}0.2 \mathrm{II}^{* *} \\
(0.090)\end{array}$ & $\begin{array}{l}0.060 \\
(0.08 \mathrm{I})\end{array}$ \\
\hline
\end{tabular}




\section{References}

Abadeer, Caroline, Alexandra Domike Blackman, Lisa Blaydes, and Scott Williamson. "Did Egypt's PostUprising Crime Wave Increase Support for Authoritarian Rule?” Working paper, 2019.

Adorno, Theodor, Else Frenkel-Brenswik, Daniel J. Levinson, and R. Nevitt Sanford. The Authoritarian Personality. Verso Books, 2019[1950].

Albertson, Bethany, and Shana Kushner Gadarian. Anxious Politics: Democratic Citizenship in a Threatening World. Cambridge University Press, 2015.

Altemeyer, Robert A. Right-Wing Authoritarianism. University of Manitoba Press, I98I.

—. The Authoritarian Specter. Harvard University Press, 1996.

Caspi, Avshalom, Brent W. Roberts, and Rebecca L. Shiner. "Personality Development: Stability and Change." Annual Review of Psychology 56 (2005): 453-484.

Davis, Darren W., and Brian D. Silver. "Civil Liberties vs. Security: Public Opinion in the Context of the Terrorist Attacks on America.” American Journal of Political Science 48, no. I (2004): 28-46.

Feldman, Stanley, and Karen Stenner. “Perceived Threat and Authoritarianism.” Political Psychology I8, no. 4 (1997): 74I-770.

Geddes, Barbara. "Why parties and elections in authoritarian regimes?" In annual meeting of the American Political Science Association, 456-471. 2005.

Gerber, Alan S., Gregory A. Huber, David Doherty, and Conor M. Dowling. "The Big Five Personality Traits in the Political Arena." Annual Review of Political Science I4 (2011): 265-287.

Greene, Samuel, and Graeme Robertson. "Agreeable Authoritarians: Personality and Politics in Contemporary Russia.” Comparative Political Studies 50, no. I3 (2017): I802-I834.

Hetherington, Marc J., and Jonathan D. Weiler. Authoritarianism and Polarization in American Politics. Cambridge University Press, 2009.

Huang, Haifeng. "Propaganda as Signaling." Comparative Politics 47, no. 4 (2015): 419-444.

Huddy, Leonie, Stanley Feldman, Charles Taber, and Gallya Lahav. "Threat, Anxiety, and Support of Antiterrorism Policies." American Journal of Political Science 49, no. 3 (2005): 593-6o8.

Jost, John T., and Orsolya Hunyady. “Antecedents and Consequences of System-Justifying Ideologies.” Current Directions in Psychological Science 14, no. 5 (2005): 260-265.

Jost, John T, Aaron C Kay, and Hulda Thorisdottir. Social and Psychological Bases of Ideology and System Justification. Oxford University Press, 2009.

Lavine, Howard, Milton Lodge, and Kate Freitas. "Threat, Authoritarianism, and Selective Exposure to Information.” Political Psychology 26, no. 2 (2005): 219-244. 
Levitsky, Steven, and Lucan A Way. Competitive Authoritarianism: Hybrid Regimes after the Cold War. Cambridge University Press, 2010.

Magaloni, Beatriz. Voting for Autocracy: Hegemonic Party Survival and its Demise in Mexico. Vol. 296. Cambridge University Press, 2006.

Merolla, Jennifer L., and Elizabeth J. Zechmeister. Democracy at Risk: How Terrorist Threats Affect the Public. University of Chicago Press, 2009.

Mutz, Diana C. Population-Based Survey Experiments. Princeton University Press, 2011.

Pepinsky, Thomas. "Southeast Asia: Voting Against Disorder." Journal of Democracy 28, no. 2 (2017): I2O-I3I.

Rickert, Edward J. “Authoritarianism and Economic Threat: Implications for Political Behavior.” Political Psychology 19, no. 4 (1998): 707-720.

Stenner, Karen. The Authoritarian Dynamic. Cambridge University Press, 2005.

Truex, Rory, and Daniel L. Tavana. "Implicit Attitudes toward an Authoritarian Regime." The Journal of Politics 8I, no. 3 (2019).

Wintrobe, Ronald. "Some Lessons on the Efficiency of Democracy from a Study of Dictatorship." In The Political Dimension of Economic Growth, 20-37. Springer, 1998. 